\title{
Endocrine, metabolic and cardioprotective effects of hexarelin in obese Zucker rats
}

\author{
V De Gennaro-Colonna, G Rossoni, D Cocchi ${ }^{1}$, \\ A E Rigamonti, F Berti and E E Muller
}

\author{
Department of Pharmacology, Chemotherapy and Medical Toxicology, University of Milan, Milan, Italy \\ ${ }^{1}$ Department of Biomedical Sciences and Biotechnologies, University of Brescia, Brescia, Italy \\ (Requests for offprints should be addressed to V De Gennaro-Colonna, Department of Pharmacology, Chemotherapy and Medical Toxicology, University of \\ Milan, Via Vanvitelli 32, 20129 Milan, Italy)
}

\begin{abstract}
Genetically obese male Zucker rats have an impaired secretion of GH, coupled to hyperinsulinemia, hyperlipidemia and glucose intolerance. The aim of this study was to evaluate whether a chronic treatment with hexarelin, a synthetic enkephalin-derived hexapeptide with a potent GH-releasing activity, might be able to ameliorate the somatotropic function and reverse some metabolic alterations associated with obesity in male obese Zucker rats. Furthermore, as decreased GH secretion and insulin resistance are associated with increased cardiovascular risk, we also tested the capacity of hexarelin to prevent postischemic ventricular dysfunction in hearts of male obese Zucker rats. Obese and lean male rats of the Zucker strain were treated with hexarelin $(80 \mu \mathrm{g} / \mathrm{kg}$, b.i.d., s.c.) or saline $(1 \mathrm{ml} / \mathrm{kg}$, b.i.d., s.c.) for 30 days. An acute hexarelin injection $(80 \mu \mathrm{g}$, s.c.) at the 28 th day of treatment elicited a rise in plasma GH levels in lean but not in obese rats (pretreated or not with hexarelin); lean rats chronically treated with hexarelin showed a greater increase in plasma $\mathrm{GH}$ as compared with control counterparts. At the end of the experiment, pituitary GH mRNA levels were significantly reduced in obese rats and hexarelin administration failed to increase pituitary GH mRNA and IGF-I concentrations in plasma and heart. Chronic treatment with
\end{abstract}

hexarelin increased insulinemia and blood glucose levels in obese but not in lean rats, left unaltered the high triglyceride levels but significantly decreased plasma cholesterol concentrations in obese rats. Heart preparations from lean and obese Zucker rats treated with saline, subjected to low flow ischemia and reperfusion, showed at reperfusion: a) a low recovery of postischemic left ventricular developed pressure (LVDP), coupled to a substantial increase in coronary perfusion pressure, and b) a marked increase in creatine kinase released in the perfusates. Hexarelin administration for 30 days counteracted the heart ischemic damage both in lean and obese Zucker rats. In fact, the recovery of LVDP at reperfusion was significantly higher than in controls and the increase in coronary resistance was minimal. Collectively, these data indicate that a 30-day treatment with hexarelin was unable to improve somatotropic function in male obese Zucker rats but was successful in decreasing plasma cholesterol concentrations. Hexarelin exerted a cardioprotective effect in both lean and obese rats. The heart-protective activity afforded by the peptide was divorced from any stimulation of the $\mathrm{GH}$ axis and is probably exerted through activation of specific cardiac receptors.

Journal of Endocrinology (2000) 166, 529-536

\section{Introduction}

Genetically obese Zucker rats represent a good model for the study of human obesity. In fact, as in humans, they present with a decrease in growth hormone $(\mathrm{GH})$ secretion (Finkelstein et al. 1986, Renier et al. 1989, Bercu et al. 1992), coupled to other endocrine (hyperinsulinemia) (Johnson et al. 1973) and metabolic (hypertriglyceridemia) (Barry \& Bray 1969) alterations. The impairment of the somatotropic axis in genetic obesity is remarkable. In fact, male obese Zucker rats show decreased pulsatile secretion of GH (Tannenbaum et al. 1990) and pituitary responsiveness to GH-releasing hormone (GHRH) (Cocchi et al.
1993), reduced pituitary GH (Ahmad et al. 1993) and hypothalamic GHRH mRNA levels (Cocchi et al. 1993). The occurrence of GH hyposecretion in genetic obesity is noteworthy since it may help in maintaining obesity once it is established; the deficiency of the known lipolytic action of GH (Lee et al. 1975) supports this view. Based on these findings, we thought it would be of interest to evaluate whether, in male obese Zucker rats, chronic treatment with hexarelin, a synthetic enkephalinderived hexapeptide with a potent GH-releasing activity (Deghenghi et al. 1994), might be able to ameliorate the somatotropic function and reverse some metabolic alterations associated with obesity. Furthermore, as decreased 
GH secretion (De Gennaro-Colonna et al. 1996) and insulin resistance (Modan et al. 1985) are associated with increased cardiovascular risk, and hexarelin proved able to exert protective cardiovascular effects in GH-deficient rats and old rats (De Gennaro-Colonna et al. 1997, Rossoni et al. 1998), we also tested the capacity of this hexapeptide to prevent postischemic ventricular dysfunction in the hearts of male obese Zucker rats. For comparison, treatment with hexarelin and evaluation of all biochemical and cardiovascular parameters were also performed in a group of male lean Zucker rats.

\section{Materials and Methods}

\section{Animals and treatments}

Male obese and lean rats of the Zucker strain (Charles River, Calco, Italy) were obtained at 30 weeks of age and were kept in a temperature-controlled environment $\left(21-23{ }^{\circ} \mathrm{C}\right)$ with a $12 \mathrm{~h}$ light: $12 \mathrm{~h}$ darkness cycle (lights on at $0700 \mathrm{~h}$ ) with free access to food and water throughout the study. Lean and obese Zucker rats were assigned to 4 experimental groups, as follows: 1) lean rats treated with saline (1 $\mathrm{ml} / \mathrm{kg}$, s.c.) (LEAN+SAL); 2) lean rats treated with hexarelin $(80 \mu \mathrm{g} / \mathrm{kg}$, b.i.d., s.c.) (LEAN+HEXA); $3)$ obese rats treated with saline $(1 \mathrm{ml} / \mathrm{kg}$, s.c.) (OBESE+SAL); 4) obese rats treated with hexarelin $(80 \mu \mathrm{g} / \mathrm{kg}$, b.i.d., s.c.) (OBESE+HEXA). The length of treatment with hexarelin or saline was 30 days, somewhat longer than that previously used in rats with selective $\mathrm{GH}$ deficiency (15 days) (De Gennaro-Colonna et al. 1997). The complexity of the experimental model used in this study, i.e. obese rats with multiple endocrine and metabolic alterations, accounts for this choice. The acute effect of hexarelin on plasma GH levels was evaluated on the 28 th day of treatment; injection of $80 \mu \mathrm{g} / \mathrm{kg}$, s.c. of the peptide or isovolumetric amounts of saline was performed at $0730 \mathrm{~h}$ and blood samples were obtained by the endo-ocular route at time 0 and 10,20, and 30 min after injection. Blood was collected into EDTA-containing tubes, centrifuged and used for the radioimmunological evaluation of plasma GH levels. Rats were killed by cervical dislocation $14 \mathrm{~h}$ after the last injection of hexarelin or saline. Pituitaries were removed, immediately frozen on dry ice and stored at $-20{ }^{\circ} \mathrm{C}$ until assayed for the determination of $\mathrm{GH}$ mRNA levels. Blood was collected into EDTA-containing tubes, centrifuged and stored at $-20{ }^{\circ} \mathrm{C}$ for insulin-like growth factor-I (IGF-I), insulin, glucose, triglyceride and cholesterol determinations. Hearts were removed and used for the radioimmunological evaluation of IGF-I concentrations or for ischemia and reperfusion experiments.

\section{GH assay in plasma}

Plasma GH concentrations were measured by a double antibody radioimmunoassay (Schalch \& Reichlin 1966).
Results were expressed in $\mathrm{ng} / \mathrm{ml}$ in terms of the National Institutes of Health standard rat GH RP-2, the potency of which was $2 \mathrm{U} / \mathrm{mg}$. The minimum detectable value of rat GH was $1 \mu \mathrm{g} / 1$; intra-assay variability was $6 \%$. To avoid interassay variation, all samples were assayed in a single radioimmunoassay.

\section{Pituitary GH $m R N A$}

Pituitary GH mRNA levels were determined by a Northern blot hybridization technique. Total RNA was isolated from each pituitary by the single-step acid guanidiniumphenol-chloroform extraction (Chomczynski \& Sacchi 1987). Total RNA samples ( $20 \mu \mathrm{g} / \mathrm{sample})$ were electrophoresed on $1 \cdot 2 \%$ formaldehyde-agarose gel and transferred to nylon membranes (Hybond N; Amersham, Little Chalfont, Bucks, UK). The membranes were hybridized with a rat GH cDNA sequence (Cella et al. 1994, De Gennaro-Colonna et al. 1996) capable of recognizing the $\mathrm{GH}$ mRNA sequence. The probe was labeled by random primer with $\alpha\left[{ }^{32} \mathrm{P}\right] \mathrm{dCTP}$ to a specific activity of $10^{9}$ d.p.m./ $\mu$ g DNA. Quantification of the hybridization signal was performed on a scanning densitometer (LKB XL Laser Densitometer, LKB, Uppsala, Sweden). Pituitary GH mRNA levels were expressed as percentage of control $(\mathrm{LEAN}+\mathrm{SAL})$ values.

\section{IGF-I in plasma and hearts}

Plasma samples were cryoprecipitated in $87.5 \%$ ethanol and $12.5 \% \mathrm{HCl}$ as previously described by Breier et al. (1991). Hearts were weighed and frozen in liquid nitrogen. Single hearts were subsequently pulverized using a tissue pulverizer and IGF-I was extracted using $1 \mathrm{~mol} / 1$ ice-cold acetic acid $(5 \mathrm{ml} / \mathrm{g}$ tissue) as previously described by D'Ercole et al. (1984). After centrifugation at $600 \boldsymbol{g}$ for $10 \mathrm{~min}$, the supernatants were frozen at $-20{ }^{\circ} \mathrm{C}$, lyophylized and reconstituted with assay buffer $(2 \mathrm{ml} / \mathrm{g}$ fresh weight). Total IGF-I circulating levels and heart IGF-I concentrations were determined using a commercially available radioimmunoassay kit. The sensitivity of the assay was $50 \mathrm{pg} / \mathrm{ml}$; intra-assay variability was less than $10 \%$. To avoid possible interassay variation, all samples were assayed in a single radioimmunoassay.

\section{Insulin, glucose, triglyceride and cholesterol assays in plasma}

Insulin was assayed by double antibody radioimmunoassay using a commercially available kit provided by ICN (Costa Mesa, CA, USA). The sensitivity of the assay was $2 \cdot 5 \mu \mathrm{IU} / \mathrm{ml}$. Intra-assay variability was less than $5 \%$.

Glucose was assayed in plasma by an enzymatic colorimetric method using a commercial kit (Peridochrom Glucosio) provided by Boehringer Mannheim (Milan, Italy). Plasma glucose concentrations are expressed in $\mathrm{mg} / \mathrm{ml}$. 
Triglycerides and cholesterol were assayed in plasma by enzymatic colorimetric methods using commercial kits (Peridochrom Trigliceridi GPO-PAP and Peridochrom cholesterol) provided by Boehringer Mannheim. Plasma triglycerides and cholesterol concentrations are expressed in $\mathrm{mg} / \mathrm{dl}$.

\section{Perfused rat heart preparations}

Hearts from the four experimental groups of rats were perfused retrogradely at $37^{\circ} \mathrm{C}$ through the aorta, following a method described by Rossoni et al. (1998). The perfusion rate of each heart, electrically paced at a frequency of 300 beats/min with rectangular impulses (by an S-88 Grass stimulator; Grass Instruments, Quincy, MA, USA), was adjusted to yield a coronary perfusion pressure (CPP) of $65-70 \mathrm{mmHg}$ with a flow rate of $15 \mathrm{ml} / \mathrm{min}$. Left ventricular pressure (LVP) was measured by inserting a small latex balloon in the ventricular cavity and filling it with saline until the left ventricular end-diastolic pressure (LVEDP) stabilized in the range of $4-5 \mathrm{mmHg}$. LVP and CPP were recorded by using HP-1280C pressure transducers (Hewlett-Packard, Waltham, MA, USA). Ischemia was induced by reducing the coronary flow to $1 \mathrm{ml} / \mathrm{min}$ for $20 \mathrm{~min}$. A normal flow rate $(15 \mathrm{ml} / \mathrm{min})$ was then restored and reperfusion continued for $30 \mathrm{~min}$. Left ventricular developed pressure $(\mathrm{LVDP}=$ peak left ventricular systolic pressure minus LVEDP) was evaluated during reperfusion. The vasopressor activity of angiotensin II ( $1 \mu \mathrm{g}$ injected as a bolus into the perfusion system) on coronary vasculature was recorded at the beginning of each experiment.

\section{6-Keto-prostaglandin $F_{1 a}$ in heart perfusates}

Prostacyclin $\left(\mathrm{PGI}_{2}\right)$ generation was measured in the heart perfusates as 6-keto-prostaglandin $\mathrm{F}_{1 \alpha}$ (6-keto-PGF $\left.\mathrm{F}_{1 \alpha}\right)$, using the enzyme immunoassay method (detection limit, $3 \mathrm{pg} / \mathrm{ml}$ ) previously described by Pradelles et al. (1985). In particular, the concentration of this stable metabolite was determined in the heart perfusates collected for $5 \mathrm{~min}$ immediately before flow reduction and during the first $10 \mathrm{~min}$ of reperfusion. The rate of formation of 6-ketoPGF $_{1 \alpha}$ was evaluated by using a specific kit (Amersham Italia, Milan, Italy) and is expressed in $\mathrm{ng} / \mathrm{min}$.

\section{Statistical analysis}

Data differences among groups in individual experiments were analyzed for statistical significance by one-way analysis of variance (ANOVA) followed by Dunnett's $t$-test for multiple comparisons. A value of $P<0 \cdot 05$ was considered significant. The areas under the curves (AUCs) were

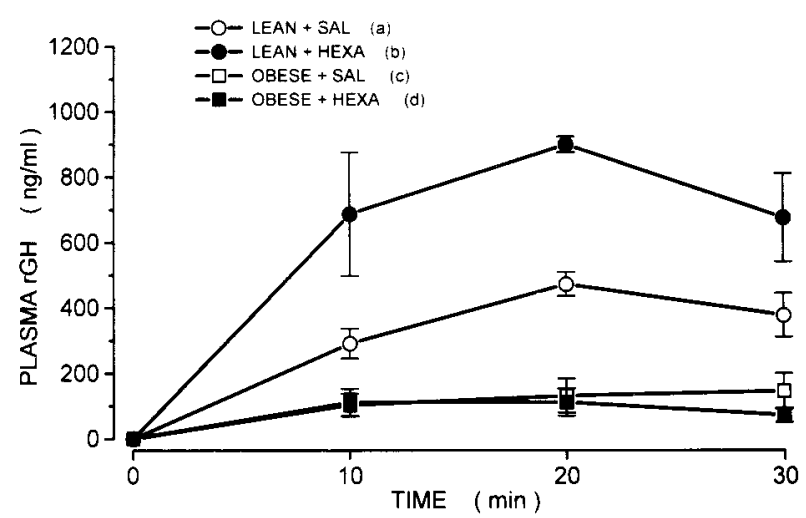

Figure 1 Effect of an acute hexarelin injection $(80 \mu \mathrm{g} / \mathrm{kg}$, s.c., administered at time 0) on plasma $\mathrm{GH}$ levels $(\mathrm{ng} / \mathrm{ml})$ in lean and obese Zucker rats of the following experimental groups: (a), LEAN+SAL $(n=6) ;(b), \operatorname{LEAN}+\operatorname{HEXA}(n=6) ;(c), \mathrm{OBESE}+\mathrm{SAL}$ $(n=6) ;(d)$, OBESE + HEXA $(n=6)$. Each point depicts mean values \pm S.E.M. The AUCs are: (a), $9550 \pm 621 \mathrm{ng} / \mathrm{ml} / 30 \mathrm{~min}$; (b), $19330 \pm 2438 \mathrm{ng} / \mathrm{ml} / 30 \mathrm{~min}$; (c), $3131 \pm 1408 \mathrm{ng} / \mathrm{ml} / 30 \mathrm{~min}$; (d), $2609 \pm 1077 \mathrm{ng} / \mathrm{ml} / 30 \mathrm{~min}$. Statistical differences: $b$ vs c and d, $P<0.001$; a vs c, $P<0.05$; a vs d, $P<0.01$; a vs $b, P<0.001$.

assessed following the trapezoid method and using the computerized program Microcal Origin (version 3.5).

\section{Results}

\section{Effect of acute hexarelin}

An acute hexarelin injection administered on the 28th day of treatment did not elicit a rise in plasma GH levels in obese rats, whether or not they were pretreated with the peptide, whereas it did elicit a significant increase in plasma GH titers in lean rats $(P<0 \cdot 001)$ (Fig. 1); lean rats chronically treated with hexarelin showed a greater increase in plasma GH compared with lean rats chronically treated with saline $(P<0 \cdot 001)$ (Fig. 1).

\section{GH $m R N A$}

Pituitary GH mRNA levels were significantly reduced in obese rats compared with lean counterparts $(-44.9 \%$, $P<0 \cdot 01$ ) (Table 1), following chronic administration of saline. Chronic treatment with hexarelin failed to increase pituitary GH mRNA in either obese or lean rats (Table 1).

\section{IGF-I concentrations in plasma and heart}

Hexarelin failed to alter IGF-I concentrations in either plasma or heart (Table 1). A trend towards a decrease in IGF-I concentrations in obese rats, treated or not with 
Table 1 Pituitary GH mRNA and IGF-I concentrations in plasma and heart of lean and obese rats. Data are mean values \pm S.E.M. of 8 rats

\begin{tabular}{|c|c|c|c|}
\hline & Pituitary GH mRNA (\%) & Plasma IGF-I (ng/ml) & Heart IGF-I (ng/g) \\
\hline \multicolumn{4}{|l|}{ Group } \\
\hline LEAN+SAL & 100 & $223 \cdot 0 \pm 13 \cdot 3$ & $6 \cdot 32 \pm 0.57$ \\
\hline LEAN + HEXA & $+5 \cdot 7 \pm 10 \cdot 0$ & $215 \cdot 4 \pm 12 \cdot 1$ & $6 \cdot 38 \pm 0.37$ \\
\hline OBESE + SAL & $-44 \cdot 9 \pm 9 \cdot 5^{\star}$ & $197 \cdot 5 \pm 10 \cdot 6$ & $4 \cdot 64 \pm 0 \cdot 33$ \\
\hline OBESE + HEXA & $-34 \cdot 5 \pm 5 \cdot 7^{*}$ & $186 \cdot 0 \pm 7 \cdot 9$ & $4 \cdot 60 \pm 0 \cdot 98$ \\
\hline
\end{tabular}

hexarelin, as compared with lean counterparts was present, although the decrease did not attain statistical significance (Table 1).

\section{Plasma insulin, glucose, triglycerides and cholesterol} concentrations

Plasma insulin concentrations were similar in lean rats treated with saline or hexarelin (Table 2), but were significantly higher in all the obese rats (Table 2). In particular, obese rats treated with hexarelin showed a further increase in plasma insulin concentrations over those present in the obese counterparts given saline (Table 2).

Obese rats treated with saline had plasma glucose concentrations similar to those found in lean animals (Table 2). Treatment with hexarelin increased plasma glucose concentrations in obese rats but not in lean rats $(P<0.05$ vs lean rats treated or not with hexarelin) (Table 2).

Irrespective of treatment with hexarelin or saline, plasma triglyceride levels were significantly higher in obese rats compared with lean rats and the same was true for cholesterol levels; hexarelin treatment in obese rats significantly decreased plasma cholesterol but not triglyceride levels (Table 2).

\section{Ischemia reperfusion in isolated rat heart}

The global reduction of flow for $20 \mathrm{~min}$ (from $15 \mathrm{ml} / \mathrm{min}$ to $1 \mathrm{ml} / \mathrm{min}$ ) in isovolumic left heart preparations obtained from saline-treated lean and obese rats induced a clear-cut decrease in left ventricular function associated with a substantial increase in coronary resistance (Fig. 2). In fact, the recovery of postischemic LVDP was low and after 30 min reperfusion only 39\% (lean rats) or 32\% (obese rats) of the preischemic strength of heart contractility was restored. At this time, CPP (mean value in the preischemic period: $65 \pm 4 \mathrm{mmHg}$ ) was still $108 \pm 9 \mathrm{mmHg}$ for lean rats and $117 \pm 10 \mathrm{mmHg}$ for obese rats (Fig. 2). In contrast, in heart preparations from hexarelin-treated lean and obese rats, there was a clear protective effect against the reperfusion damage (Fig. 2). In fact, at reperfusion, the recovery of postischemic left ventricular function was in the range of $73 \%$ (lean rats) or $70 \%$ (obese rats) of the preischemic strength, at the end of reperfusion (Fig. 2). In these preparations, CPP values increased only minimally in the first $5 \mathrm{~min}$ of reperfusion and at the end of this period they were only $67 \pm 4 \mathrm{mmHg}$ for LEAN+HEXA and $74 \pm 6 \mathrm{mmHg}$ for OBESE+HEXA rats (Fig. 2).

Bolus injection of angiotensin II $(1 \mu \mathrm{g})$ in the perfusion system of hearts from rats (lean and obese) treated with saline or hexarelin induced an increase in CPP not statistically different in the four experimental groups (data not shown), thus implying that hexarelin did not interfere with the endothelium-dependent relaxant function of the coronary vasculature.

\section{Creatine kinase determinations}

Results of creatine kinase (CK) activity released in the perfusates during reperfusion were in keeping with the

Table 2 Plasma insulin, glucose, triglycerides and cholesterol concentrations in lean and obese rats. Data are mean values \pm S.E.M. of 8 rats

\begin{tabular}{|c|c|c|c|c|}
\hline & $\begin{array}{l}\text { Insulin } \\
(\mu \mathrm{IU} / \mathrm{ml})\end{array}$ & $\begin{array}{l}\text { Glucose } \\
(\mathrm{mg} / \mathrm{dl})\end{array}$ & $\begin{array}{l}\text { Triglycerides } \\
(\mathrm{mg} / \mathrm{dl})\end{array}$ & $\begin{array}{l}\text { Cholesterol } \\
(\mathrm{mg} / \mathrm{dl})\end{array}$ \\
\hline \multicolumn{5}{|l|}{ Group } \\
\hline LEAN+SAL & $63 \cdot 9 \pm 18 \cdot 5$ & $124 \cdot 3 \pm 4 \cdot 3$ & $74 \cdot 0 \pm 10 \cdot 9$ & $124 \cdot 8 \pm 9 \cdot 1$ \\
\hline LEAN + HEXA & $50 \cdot 1 \pm 3 \cdot 6$ & $116 \cdot 4 \pm 5 \cdot 6$ & $77 \cdot 5 \pm 10 \cdot 5$ & $120 \cdot 1 \pm 8 \cdot 1$ \\
\hline OBESE+SAL & $406 \cdot 7 \pm 65 \cdot 4^{*}$ & $135 \cdot 0 \pm 3 \cdot 3$ & $419 \cdot 2 \pm 76 \cdot 8^{*}$ & $382 \cdot 2 \pm 18 \cdot 3^{*}$ \\
\hline OBESE+HEXA & $785 \cdot 1 \pm 149 \cdot 1^{*} \dagger$ & $147 \cdot 8 \pm 10 \cdot 2^{*}$ & $400 \cdot 1 \pm 72 \cdot 9^{*}$ & $303 \cdot 8 \pm 35 \cdot 7^{*} \dagger$ \\
\hline
\end{tabular}

${ }^{*} P<0 \cdot 05$ vs LEAN + SAL and LEAN + HEXA; $† P<0 \cdot 05$ vs OBESE + SAL. 

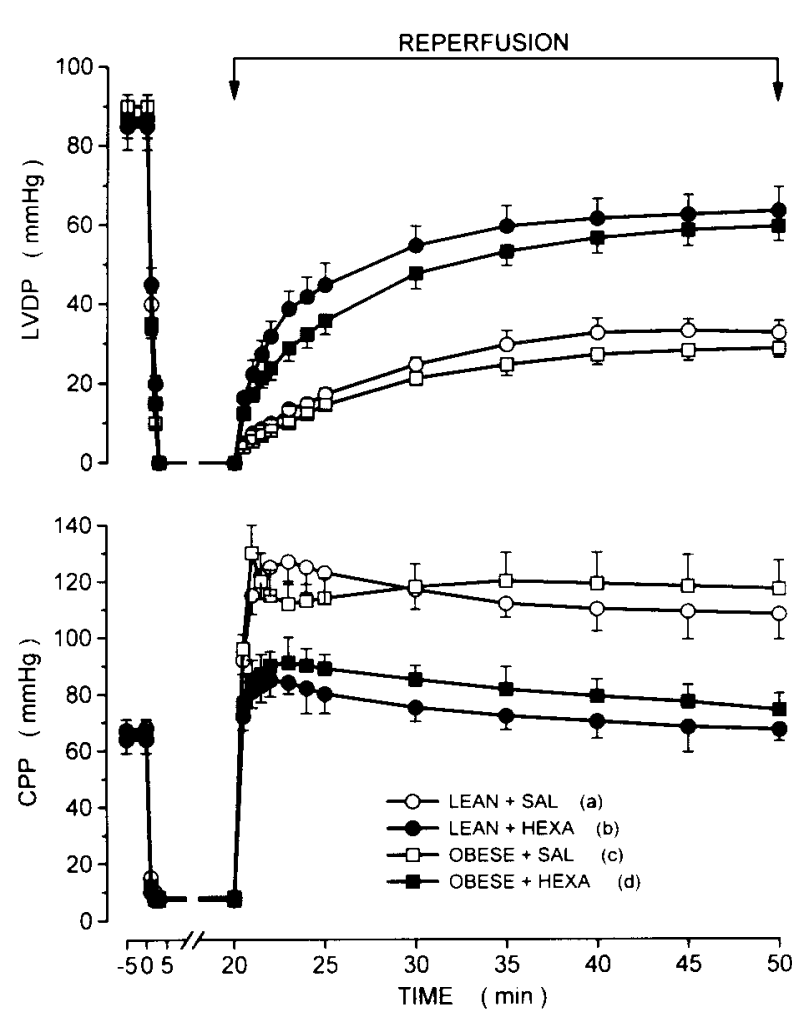

Figure 2 Left ventricular developed pressure (LVDP) and coronary perfusion pressure (CPP) in isovolumic left heart preparations submitted to low-flow ischemia and reperfusion from lean and obese Zucker rats of the following experimental groups: (a), LEAN + SAL $(n=7) ;(b), \operatorname{LEAN}+\operatorname{HEXA}(n=6) ;(\mathrm{c}), \mathrm{OBESE}+\mathrm{SAL}$ $(n=7)$; (d), OBESE+HEXA $(n=7)$. Each point depicts mean values \pm S.E.M. The AUCs related to LVDP are: (a), $789 \pm 66$; (b), $1633 \pm 142$; (c), $667 \pm 57$; (d), $1451 \pm 123$. Statistical differences: $a$ and $c$ vs $b$ and $d, P<0 \cdot 001$. The AUCs related to $\mathrm{CPP}$ (increase in $\mathrm{mmHg}$ over the preischemic values) are: (a), $1441 \pm 135$; (b), $332 \pm 38$; (c), $1545 \pm 108$; (d), $422 \pm 56$. Statistical differences: $a$ and $c$ vs $b$ and $d, P<0 \cdot 001$.

AUCs were estimated according to the trapezoid method: ordinate, LVDP or CPP in $\mathrm{mmHg}$; abscissa, time from 20 to 50 min.

different extent of the myocardial ischemia injury occurring in the hexarelin- or saline-treated rats. In fact, at the peak effect, the release of $\mathrm{CK}$ in cardiac outflow of hearts taken from lean and obese control rats was increased 6.7-fold (from $47 \pm 6$ to $313 \pm 27 \mathrm{mU} / \mathrm{min} / \mathrm{g}$ wet tissue) and $6 \cdot 6$-fold (from $50 \cdot 0 \pm 6$ to $339 \pm 25 \mathrm{mU} / \mathrm{min} / \mathrm{g}$ wet tissue) respectively. In contrast, in hearts obtained from lean and obese hexarelin-treated rats, the values of CK measured in cardiac perfusates were increased only $2 \cdot 4-$ fold (from $55 \pm 5$ to $133 \pm 15 \mathrm{mU} / \mathrm{min} / \mathrm{g}$ wet tissue) and $2 \cdot 8$-fold (from $58 \cdot 0 \pm 5$ to $163 \cdot 0 \pm 14 \mathrm{mU} / \mathrm{min} / \mathrm{g}$ wet tissue) respectively (Fig. 3).

\section{6-Keto-PGF 1 generation}

The rate of release of 6-keto-PGF ${ }_{1 \alpha}$ in the heart perfusates during the preischemic period (range: $1 \cdot 9 \pm 0 \cdot 3$ to

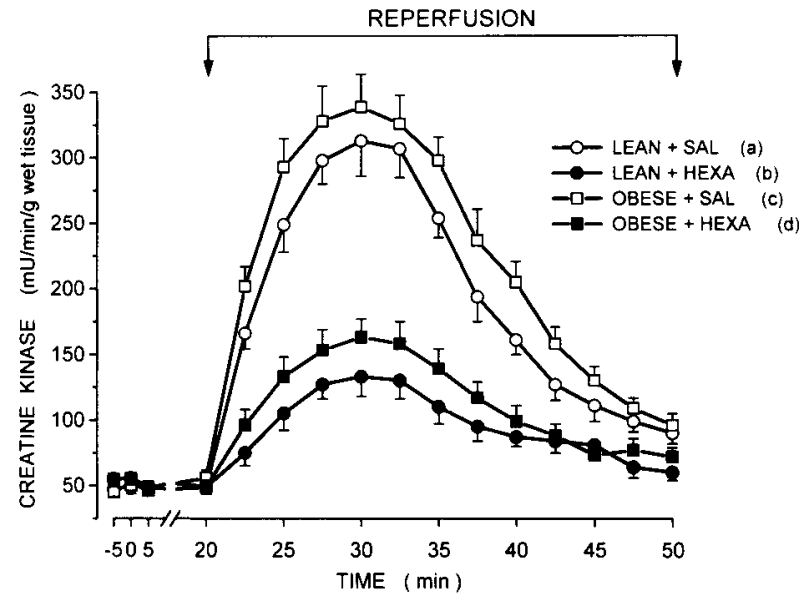

Figure 3 Creatine kinase (CK) release profile in ischemic and reperfusion conditions of lean and obese Zucker rats chronically treated with either saline (SAL) or hexarelin (HEXA) (for $n$ see legend to Fig. 2). Each point depicts mean values \pm S.E.M. The AUCs related to CK release during reperfusion are: (a), $4371 \pm 385$; (b), $1463 \pm 132$; (c), $5252 \pm 418$; (d), $1791 \pm 158$. Statistical differences: $a$ and $c$ vs $b$ and $d, P<0 \cdot 001$.

$2 \cdot 5 \pm 0.2 \mathrm{ng} / \mathrm{ml}$ ) was not statistically different in the four experimental groups under investigation (Fig. 4). As expected, during the first $10 \mathrm{~min}$ of reperfusion, the generation of the prostacyclin metabolite increased by the same amount (about 5-fold) in the hearts obtained from the four experimental groups. Hexarelin treatment did not enhance prostacyclin production from the hearts during reperfusion (Fig. 4). This would indicate that the beneficial effect exerted by hexarelin in postischemic left

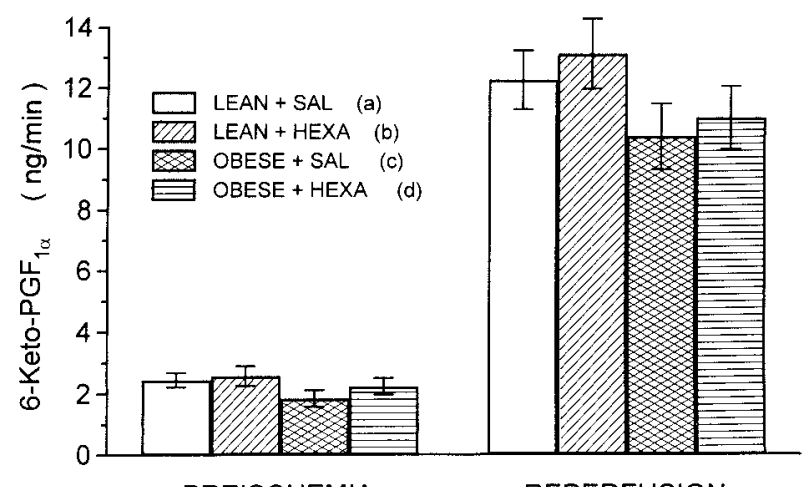

PREISCHEMIA

REPERFUSION

Figure 4 Rate of release of 6-keto- $\mathrm{PGF}_{1 \alpha}$ in perfusates of isovolumic left heart preparations from lean and obese Zucker rats chronically treated with either saline (SAL) or hexarelin (HEXA) (for $n$ see legend to Fig. 2). Columns represent mean values \pm S.E.M. Perfusates were collected during preischemia (5 min) and reperfusion (first $10 \mathrm{~min}$ ). Values obtained during preischemia are statistically different from those of reperfusion, $P<0 \cdot 001$. 
ventricular dysfunction was not related to further stimulation of 6-keto-PGF ${ }_{1 \alpha}$ formation by the heart tissues.

\section{Discussion}

In the present study, obese Zucker rats, under baseline conditions, showed a decreased GH response to a hexarelin challenge and had a reduced pituitary content of $\mathrm{GH}$ mRNA; this was in agreement with previous reports (Renier et al. 1989, Cocchi et al. 1993). Plasma IGF-I levels were not significantly different in lean and obese male Zucker rats, a finding confirming previous reports in male Zucker (Cocchi et al. 1993) and male overfed rats (Cattaneo et al. 1996), while in female Zucker rats, higher plasma IGF-I levels were reported in obese rats compared with lean rats (Bercu et al. 1992 , Cocchi et al. 1993). Impairment of the somatotropic axis was coupled to other endocrine and metabolic alterations. In fact, obese Zucker rats (this study) were also hyperinsulinemic (with normal blood glucose levels) and had hypertriglyceridemia and hypercholesterolemia. Hyperinsulinemia with normal plasma glucose concentrations is a consistent feature of obese Zucker rats and has been reported by Zucker \& Zucker (1962) and Tannenbaum et al. (1990). Elevated plasma triglycerides have also been reported in obese Zucker rats (Barry \& Bray 1969), while in female Zucker rats, plasma cholesterol concentrations were found to be similar in obese and lean animals (Bercu et al. 1992).

Hexarelin treatment for 30 days apparently did not improve somatotropic function in obese Zucker rats, as shown by the inability of the peptide to elicit a plasma GH response and to increase pituitary GH mRNA levels. In lean rats, acute administration of hexarelin elicited a consistent rise in plasma GH titers and this was particularly evident in hexarelin-pretreated rats, although differences in stimulated GH secretion between the two groups of lean rats (given saline or hexarelin chronically) did not attain statistical significance. These data are in agreement with those of Bercu et al. (1992) in female Zucker rats. In fact, in that study, a two-month treatment with GHreleasing peptide-6 (GHRP-6)+GHRH failed to increase the GHRH-stimulated GH secretion.

In our study, plasma IGF-I levels were unchanged by the peptide treatment, both in lean and obese rats. The inability of another GHRP analog (G7039), administered for 24 days, to increase serum IGF-I levels in male Zucker diabetic fatty rats has previously been reported by Clark et al. (1997); also female obese Zucker rats coadministered GHRP-6 and GHRH for 45 days did not show significant increases in plasma IGF-I (Bercu et al. 1992).

Concerning the metabolic alterations following chronic treatment with hexarelin to obese Zucker rats, insulinemia was further increased by hexarelin and this was coupled to increased blood glucose levels. One possibility is that these findings may be related to the ability of hexarelin to stimulate the hypothalamic-pituitary-adrenal (HPA) axis.
Reportedly, some GHRPs can release corticosteroids (Hickey et al. 1994, Friboes et al. 1995, Clark et al. 1997) and although the mechanism by which GHRPs stimulate the HPA axis is unknown, it probably underlies a hypothalamic action since no effect on adrenocorticotropin release from isolated pituitary cells has been observed (Smith et al. 1996).

The effect of hexarelin on blood lipids of obese Zucker rats was interesting. In fact, while triglyceride levels were unmodified, plasma cholesterol concentrations in obese rats given hexarelin were significantly lower than those of control obese rats. These findings are in agreement with recent results obtained by our group in beagle dogs treated with hexarelin for 16 weeks (A Rigamonti, unpublished data) and, to the best of our knowledge, they represent the first demonstration that hexarelin has a cholesterollowering effect. It is tempting to suggest that this effect might contribute to the cardioprotective activity displayed by the peptide in rats (De Gennaro-Colonna et al. 1997). In this study, we have not evaluated the plasma levels of low density lipoprotein (LDL)/high density lipoprotein (HDL) cholesterol, but our finding of decreased cholesterol levels in hexarelin-treated obese rats could be due to a decrease in LDL cholesterol with minor changes in HDL cholesterol. In fact, it has been shown in humans that both the GHRP-induced GH release and activation of the HPA axis cause changes in lipoprotein metabolism, decreasing LDL cholesterol and increasing HDL cholesterol (Berg \& Nilsson-Ehle 1994, Beshyah et al. 1995). Furthermore, changes in the levels of each plasma lipoprotein and, obviously, of total cholesterol seem dependent on the length of GHRP treatment. Svensson et al. (1999) reported that the administration of MK-677, a non peptidyl $\mathrm{GH}$ secretagog, to obese males induced, after two weeks of treatment, a significant increase in plasma HDL cholesterol and total cholesterol levels, leaving LDL cholesterol unaltered. When the length of treatment was increased, a trend towards a decrease in LDL cholesterol was also evident so that, at the end of treatment (eight weeks), the LDL/HDL cholesterol ratio was significantly reduced (Svensson et al. 1999). In this vein, the increased plasma total cholesterol levels reported by Clark et al. (1997) in the Zucker diabetic fatty rats treated with G7039 for 24 days might reflect an increase in HDL cholesterol with minor changes in LDL cholesterol. The discrepancy between our findings and those of Clark et al. (1997) might also result from the different lengths of treatment with the two GHRPs (30 days for hexarelin and 24 days for G7039) as well as the different potency of the two synthetic peptides in releasing GH and activating the HPA. Studies are now in progress in our laboratory to evaluate plasma lipoprotein levels after various lengths of treatment with hexarelin in obese Zucker rats.

Our results from perfused rat heart preparations submitted to low-flow ischemia and reperfusion clearly confirm that hexarelin has a protective action against postischemic 
ventricular dysfunction in hearts from lean rats, and extend these observations to obese rats. In fact, heart preparations from both lean and obese hexarelin-treated rats showed a much better recovery of postischemic left ventricular function compared with heart preparations from salinetreated rats. This was associated with a decrease in coronary artery resistance upon reperfusion, denoting a lesser degree of heart stiffness. In keeping with these results, the total amount of CK released from hearts of hexarelin-treated animals during 30-min reperfusion was significantly reduced compared with that found in perfusates of saline-treated rats. This result bespeaks the integrity of myocardial cell membranes and their preservation from the contractile impairment that follows oxygen readmission.

The cardioprotective effect of hexarelin has also been demonstrated by our group in GH-deficient (De Gennaro-Colonna et al. 1997, Locatelli et al. 1999) and in aged rats (Rossoni et al. 1998). An interesting finding from our present results is that hexarelin manifested a strong heart protective action with no evidence of stimulation of the somatotropic axis, especially in obese Zucker rats. Overall, these findings strengthen the view that hexarelin acts, at least in part, via a GH-independent mechanism and through specific cardiac receptors, and triggers presently unknown cytoprotective mechanisms responsible for the resistance to the ischemic insult. Favoring this type of reasoning, Muccioli et al. (1999a,b) recently reported the presence of binding sites for hexarelin in the cardiovascular system (ventricles, atria, aorta, coronaries, carotid).

In our study, we also investigated the ability of the cardiac tissues to generate 6-keto-PGF ${ }_{1 \alpha}$, the stable metabolite of prostacyclin, the increase of which during the reperfusion period would contribute to the limitation of the reperfusion injury (Berti et al. 1987, 1988). Chronic treatment with hexarelin failed, however, to increase production of this eicosanoid by the cardiac endothelium in all experimental groups. This negative finding is also consistent with the inability of hexarelin to alter the vasopressor activity of angiotensin II on the coronary vessels. Overall, these data indicate that in lean and obese Zucker rats, in contrast to rats treated with anti-GHRH serum (De Gennaro-Colonna et al. 1997) or hypophysectomized rats (Rossoni et al. 1999), there is neither an evident impairment of the vascular endotheliumdependent relaxing function nor is hexarelin capable of improving the endothelial vasodilation mechanisms. A tentative explanation of these results is that a clear dysfunction of the endothelium-dependent relaxing mechanisms is present only when the somatotropic function is lacking or is profoundly impaired, such as in hypophysectomized or anti-GHRH-treated rats respectively, but not when the GH secretion is decreased to a lesser extent, such as in obese Zucker rats.

In conclusion, these findings indicate that a 30-day treatment with hexarelin was unable to improve somato- tropic function in male obese Zucker rats but was successful in decreasing plasma cholesterol concentrations and providing cardioprotection following ischemia. Since the genetically obese Zucker rat is a widely used model of human non-insulin-dependent (type II) diabetes mellitus (Bray 1977) in which cardiovascular disease is a major cause of morbidity and mortality, the potential benefit that hexarelin may induce in these patients does not escape attention.

\section{References}

Ahmad I, Finkelstein JA, Downs TR \& Frohman LA 1993 Obesity-associated decrease in growth hormone-releasing hormone gene expression: a mechanism for reduced growth hormone mRNA levels in genetically obese Zucker rats. Neuroendocrinology $\mathbf{5 8}$ 332-337.

Barry WS \& Bray GA 1969 Plasma triglycerides in genetically obese rats. Metabolism 18 833-839.

Bercu BB, Yang S-W, Masuda R, Hu C-S \& Walker RF 1992 Effects of coadministered growth-hormone (GH)-releasing hormone and GH-releasing hexapeptide on maladaptive aspects of obesity in Zucker rats. Endocrinology 131 2800-2804.

Berg A-L \& Nilsson-Ehle P 1994 Direct effects of corticotropin on plasma lipoprotein metabolism in man - studies in vivo and in vitro. Metabolism 43 90-97.

Berti F, Rossoni G, Omini C, Folco G, Daffonchio L, Viganò T \& Tondo C 1987 Defibrotide, an antithrombotic substance which prevents myocardial contracture in ischemic rabbit heart. European Journal of Pharmacology 135 375-382.

Berti F, Rossoni G, Magni G, Caruso D, Omini C, Puglisi L \& Galli G 1988 Nonsteroidal anti-inflammatory drugs aggravate acute myocardial ischemia in the perfused rabbit heart: a role for prostacyclin. Journal of Cardiovascular Pharmacology 12 438-444.

Beshyah SA, Henderson A, Niththyananthan R, Skinner E, Anyaoku V, Richmond W, Sharp P \& Johnston DG 1995 The effects of short and long term growth hormone replacement therapy in hypopituitary adults on lipid metabolism and carbohydrate tolerance. Journal of Clinical Endocrinology and Metabolism 80 356-363.

Bray GA 1977 The Zucker-fatty rat: a review. Federation Proceedings 36 148-153.

Breier HB, Gallaher BW \& Gluckman PD 1991 Radioimmunoassay for insulin-like growth factor-I: solutions to some potential problems and pitfalls. Journal of Endocrinology 128 347-357.

Cattaneo L, De Gennaro-Colonna V, Zoli M, Muller EE \& Cocchi D 1996 Characterization of the hypothalamo-pituitary-IGF-I axis in rats made obese by overfeeding. Journal of Endocrinology 148 347-353.

Cella SG, De Gennaro-Colonna V, Locatelli V, Bestetti GE, Rossi GL, Torsello A, Wehrenberg WB \& Muller EE 1994 Somatotropic dysfunction in growth hormone-releasing hormone-deprived neonatal rats: effect of growth hormone replacement therapy. Pediatric Research 36 315-322.

Chomczynski P \& Sacchi N 1987 Single-step method of RNA isolation by acid guanidinium thiocyanate-phenol-chloroform extraction. Analytical Biochemistry 162 156-159.

Clark RG, Thomas GB, Mortensen WB, Won WB, Ma YH, Tomlinson EE, Fairhall KM \& Robinson ICAF 1997 Growth hormone secretagogues stimulate the hypothalamic-pituitary-adrenal axis and are diabetogenic in the Zucker diabetic fatty rat. Endocrinology 138 4316-4323.

Cocchi D, Parenti M, Cattaneo L, De Gennaro-Colonna V, Zocchetti A \& Muller EE 1993 Growth hormone secretion is differently affected in genetically obese male and female rats. Neuroendocrinology 57 928-934. 
De Gennaro-Colonna V, Rossoni G, Bonacci D, Ciceri S, Cattaneo L \& Muller EE 1996 Worsening of ischemic damage in hearts from rats with selective growth hormone deficiency. European Journal of Pharmacology 314 333-338.

De Gennaro-Colonna V, Rossoni G, Bernareggi M, Muller EE \& Berti F 1997 Cardiac ischemia and impairment of vascular endothelium function in hearts from $\mathrm{GH}$-deficient rats: protection by hexarelin. European Journal of Pharmacology 334 201-207.

Deghenghi R, Cananzi MM, Torsello A, Battisti C, Muller EE \& Locatelli V 1994 GH-releasing activity of Hexarelin, a new growth hormone-releasing peptide, in infant and adult rats. Life Science $\mathbf{5 4}$ 1321-1328.

D'Ercole AJ, Stiles AD \& Underwood LE 1984 Tissue concentration of somatomedin C: further evidence for multiple sites of synthesis and paracrine or autocrine mechanism of action. PNAS $\mathbf{8 1}$ 935-939.

Finkelstein JA, Bervois P, Mendue M \& Willougby JO 1986 Growth hormone and prolactin secretion in genetically obese Zucker rats. Endocrinology 118 1233-1236.

Friboes RM, Murck H, Maier P, Schier T, Holsboer F \& Steiger A 1995 Growth hormone-releasing peptide-6 stimulates sleep, growth hormone, ACTH and cortisol release in normal man. Neuroendocrinology 61 584-589.

Hickey G, Jacks T, Judith F, Taylor J, Schoen WR, Krupa D, Cunningham P, Clark J \& Smith RG 1994 Efficacy and specificity of 1-692,429, a novel nonpeptidyl growth hormone secretagogue, in beagles. Endocrinology 134 695-701.

Johnson PR, Stern JS \& Greenwood MRC 1973 Effect of early nutrition on adipose cellularity and pancreatic insulin release in the Zucker rat. Journal of Nutrition 102 738-743.

Lee V, Ramachandran J \& Li CH 1975 Human pituitary growth hormone: intrinsic lipolytic activity in rabbit fat cells. Archives of Biochemistry and Biophysics 169 669-677.

Locatelli V, Rossoni G, Schweiger F, Torsello A, De GennaroColonna V, Bernareggi M, Deghenghi R, Muller EE \& Berti F 1999 Growth hormone-independent cardioprotective effects of hexarelin in the rat. Endocrinology 140 4024-4031.

Modan M, Halkin H, Almay S, Lusky A, Eshkil M, Shitrit A \& Fuchs A 1985 Hyperinsulinemia: a link between hypertension, obesity and glucose intolerance. Journal of Clinical Investigation $\mathbf{7 5}$ 809-817.

Muccioli G, Ghè C, Catapano F, Papotti M, Deghenghi R \& Ghigo E 1999a Binding of hexarelin to human heart membranes. Pharmacological Research 39 (Suppl) p 28 (Abstract). (Abstracts presented at the XXIX National Congress of the Italian Pharmacological Society.)
Muccioli G, Papotti M, Graziani A, Deghenghi R \& Ghigo E 19996 Binding of hexarelin to membranes from human heart and blood vessels. Program of the 81st Meeting of the Endocrine Society, San Diego CA, USA, p 380 (Abstract).

Pradelles P, Grassi J \& Maclouf J 1985 Enzyme immunoassays of eicosanoids using acetylcholine esterase as label: an alternative to radioimmunoassay. Analytical Chemistry 57 1170-1173.

Renier G, Gaudreau P, Deslauries C \& Brazeau P 1989 in vitro and in vivo growth hormone responsiveness to growth hormone-releasing factor in male and female Zucker rats. Neuroendocrinology $\mathbf{5 0}$ 454-459.

Rossoni G, De Gennaro-Colonna V, Bernareggi M, Polvani GL, Muller EE \& Berti F 1998 Protectant activity of hexarelin or growth hormone against postischemic ventricular dysfunction in hearts from aged rats. Journal of Cardiovascular Pharmacology 32 260-265.

Rossoni G, Locatelli V, De Gennaro-Colonna V, Torsello A, Schweiger F, Boghen M, Nilsson M, Bernareggi M, Muller EE \& Berti F 1999 Growth hormone and hexarelin prevent endothelial vasodilator dysfunction in aortic rings of the hypophysectomized rat. Journal of Cardiovascular Pharmacology 34 454-460.

Schalch DS \& Reichlin S 1966 Plasma growth hormone concentration in the rat determined by radioimmunoassay. Endocrinology 73 275-280.

Smith RG, Pong S-S, Hickey G, Jacks T, Cheng K, Leonard R, Cohen CJ, Arean JP, Chang CH, Drisko J, Wyvratt M, Fisher M, Nargund R \& Pathcett A 1996 Modulation of pulsatile GH release through a novel receptor in hypothalamus and pituitary gland. Recent Progress in Hormone Research 51 261-286.

Svensson J, Jansson J-O, Ottosson M, Johannsson G, Taskinen M-R, Wiklund O \& Bengtsson B-A 1999 Treatment of obese subjects with the oral growth hormone secretagogue MK-677 affects serum concentrations of several lipoproteins, but not lipoprotein(a). Journal of Clinical Endocrinology and Metabolism 84 2028-2033.

Tannenbaum GS, Lapointe M, Gurd F \& Winkelstein JA 1990 Mechanisms of impaired growth hormone secretion in genetically obese Zucker rats: role of growth hormone releasing factor and somatostatin. Endocrinology 127 3087-3095.

Zucker TF \& Zucker LM 1962 Hereditary obesity in the rat associated with high serum fat and cholesterol. Proceedings of the Society for Experimental Biology and Medicine 110 165-171.

Received 5 January 2000

Accepted 4 May 2000 